\title{
Dilema Peran Ganda Dosen Perempuan Selama Pandemi Covid-19 di Indonesia
}

\author{
Muhammad Haekal ${ }^{1}$, Ainal Fitri2 \\ DOI: https://doi.org/10.36339/jaspt.v4i2.366
}

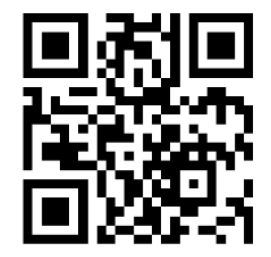

\begin{abstract}
Abstrak
Penelitian kualitatif ini menginvestigasi bagaimana tantangan dosen perempuan ketika bekerja selama pandemi Covid-19. Penelitian ini melibatkan lima belas dosen perempuan dari berbagai perguruan tinggi di Sumatra dan Jawa. Peneliti menyebarkan pertanyaan penelitian secara daring dan menganalisa temuan dengan menggunakan pendekatan konsep kerja yang dikemukakan oleh feminis bell hooks. Temuan menunjukkan masih adanya eksploitasi gender di sebagian tempat kerja dan rumah tangga, namun juga berisi harapan bahwa masih ada tempat privat dan publik yang menjunjung tinggi keadilan gender. Penelitian ini berkontribusi terhadap pemahaman terkait keadilan gender di konteks pendidikan tinggi selama pandemi. Kekurangan penelitian ini adalah responden yang hanya dosen perempuan, tanpa melibatkan pekerja perempuan lain dalam bidang administratif, kebersihan, dan keamanan di perguruan tinggi.
\end{abstract}

Kata Kunci: gender, feminisme, pendidikan tinggi, dosen perempuan.

\section{Abstract}

This qualitative research investigates the challenges of female lecturers while working during the Covid-19 pandemic. This research involved fifteen female lecturers from various universities in Sumatra and Java. Researchers distributed research questions online and analyzed the findings using the work concept proposed by bell hooks. The findings show that there is still gender exploitation in some workplaces and households, but also contain the hope that there are still private and public places that uphold gender justice. This research contributes to understanding related to gender justice in the context of higher education during the pandemic. The weakness of this study is that the respondents are only female lecturers, without involving other female workers in the administrative, sanitary, and security fields of universities.

Keywords: gender, feminism, higher education, female academics.

\section{PENDAHULUAN}

Universitas, seperti halnya satuan pendidikan lain yang ada di Indonesia, juga turut terdampak oleh pandemi Covid-19. Pembelajaran berubah ke mode daring dan dalam banyak kesempatan berlangsung dari rumah. Perubahan lokasi belajar dari kampus ke rumah seakan adalah proses yang wajar atau biasa saja. Namun nyatanya, perubahan ini berdampak tersendiri bagi dosen perempuan. Mereka tidak hanya mesti beradaptasi

Ar-Raniry State Islamic University, Jl. Ar-Raniry Kopelma Darussalam, Banda Aceh 23111, Indonesia 2. Serambi Mekkah University, JI. Unmuha, Batoh, Kec. Lueng Bata, Banda Aceh 23245 , Indonesia

\section{Email:}

1 muhammad.haekal@ar-

raniry.ac.id
Submitted : Oktober 2020

Accepted : Desember 2020
JAS-PT

JURNAL ANAUISIS SISTEM PENDIDIKAN TING

ISSN $2580-5339$

elSSN $2620-5718$

Volume 4

Nomor 2

DESEMBER 2020

Hal 171 - 182

FORUM DOSEN INDONESIA 
dengan kebijakan baru kampus selama pandemi, tapi juga bernegosiasi dengan budaya patriarki yang masih kokoh di sebagian rumah tangga Indonesia.

Penelitian tentang dampak pandemi Covid-19 terhadap perempuan sudah banyak dilakukan seiring tren penelitian tentang pandemi yang meningkat akhir-akhir ini. Sebuah studi di Amerika Serikat (AS) menyebutkan, pandemi paling tidak menyebabkan dua perubahan: pertama, pergantian peraturan kerja menjadi semakin fleksibel; kedua, perubahan norma sosial di rumah terkait peran istri dan suami (Alon, Doepke, OlmsteadRumsey, \& Tertilt, 2020). Banyak perusahaan di AS secara adaptif mengganti mode kerja menjadi daring. Walau kami juga menilai, pergantian mode kerja daring lebih menguntungkan pekerja kerah putih, dan hal sebaliknya terjadi pada pekerja kerah biru. Di ranah domestik, pandemi menjadikan terjadinya negosiasi antara istri dan suami dalam perawatan anak.

Lebih lanjut, penutupan sekolah dan penitipan anak selama pandemi membuat orang tua pekerja tak hanya berkewajiban menjaga anak, namun juga menjadi guru yang menyediakan pendidikan alternatif bagi anak mereka. Hal tersebut semakin terasa di keluarga yang memiliki anak usia sekolah dasar atau lebih muda lagi, di mana kebutuhan perawatan dan pendidikan sedang pada tahap intens. Sebuah temuan di keluarga heteroseksual menyebutkan, istri pekerja lebih cenderung mendapat pengurangan jam kerja profesional mereka ketimbang suami pekerja (Collins, Landivar, Ruppanner, \& Scarborough, 2020). Namun, studi tersebut tidak menjelaskan lebih lanjut mengapa pengurangan jam bekerja itu terjadi pada istri pekerja, misalnya apakah kebijakan tersebut ada karena imajinasi perusahaan terkait dominannya peran istri di rumah.

Di Malaysia, sebuah negara dengan budaya patriarki yang kental, peran perempuan lebih berpusat di rumah, terlepas posisinya sebagai ibu rumah tangga atau perempuan karir. Saat pandemi Covid-19 bulan Maret lalu, pemerintah Malaysia memberlakukan karantina wilayah selama dua minggu. Pemerintah hanya membolehkan kepala keluarga (laki-laki) keluar rumah, misalnya untuk membeli kebutuhan hidup. Sedangkan perempuan, terlepas mereka memiliki pekerjaan misalnya sebagai petugas kesehatan, mesti menjalani hari-hari dengan risiko mendapatkan denda atau tuntutan hukum dari aparat keamanan yang mengawal kebijakan karantina wilayah tersebut (McLaren, Wong, Nguyen, \& Mahamadachchi, 2020). Hal ini menunjukkan, kurangnya sensitivitas gender dari pengambil kebijakan tidak hanya berdampak buruk pada individu perempuan serta keluarganya, namun juga pada pelayanan publik khususnya sektor kesehatan yang tengah dalam kondisi hiruk-pikuk selama pandemi ini.

Di ranah akademik, sebuah studi mencatat penurunan jumlah publikasi oleh akademisi perempuan selama pandemi Covid-19 (Andersen, Nielsen, Simone, Lewiss, \& Jagsi, 2020). Temuan ini penting, walau sebenarnya bukanlah hal yang secara khusus terjadi pada saat pandemi. Sebelum pandemi pun, akademisi perempuan di berbagai tempat masih bergelut dengan budaya patriarki di universitas, kurangnya mentor perempuan dan kesempatan mendapatkan hibah, termasuk berhadapan dengan isu lama seperti stereotip gender di rumah tangga (Howe-Walsh \& Turnbull, 2016).Studi-studi tersebut menunjukkan pandemi ini semakin menambah tekanan yang telah ada sebelumnya di

JAS-PT

JURNAL ANALISIS SISTEM PENDIDIKAN TINGG

ISSN 2580 - 5339

eISSN 2620 - 5718

Volume 4

Nomor 2

DESEMBER 2020

Hal 171 - 182

FORUM DOSEN INDONESIA kehidupan akademisi perempuan.

Sebelum Covid-19 mewabah, di Indonesia telah marak pula riset mengenai dosen perempuan. Dosen perempuan masih menghadapi kesulitan dalam memimpin di perguruan tinggi yang tidak ramah gender serta meyakini bahwa kapasitas kepemimpinan hanya dimiliki oleh dosen laki-laki (Karniawati, 2013). Hal ini terjadi khususnya di institusi yang memiliki pandangan tekstual terhadap ajaran Islam. Penelitian lain menemukan hubungan kelelahan kerja berlebihan dengan keseimbangan 
hidup-pekerjaan dosen perempuan. Beban kerja yang menumpuk membuat dosen perempuan kesulitan mencapai kebahagiaan dalam kehidupannya (Darmawan, Silviandari, \& Susilawati, 2016). Sebuah riset lain menemukan kaitan antara dukungan suami terhadap tingkat stres dosen perempuan. Semakin tinggi dukungan suami, maka semakin rendah stres dosen perempuan (Kumolohadi, 2001). Riset-riset tersebut menunjukkan kebijakan yang adil dan proporsional di dunia kerja, serta dukungan yang baik di rumah tangga, memberikan dampak positif bagi kehidupan personal dan profesional dosen perempuan.

Penelitian kualitatif ini sendiri berusaha menjawab beberapa pertanyaan: Selama pandemi Covid-19, apa perbedaan dan kesamaan isu dosen perempuan di Indonesia dengan negara lain? Bagaimana imbas pandemi bagi dosen perempuan di universitasuniversitas di Indonesia? Bagaimana kelas sosial berpengaruh terhadap kinerja mereka? Bagaimana mereka mengatur keseimbangan antara kehidupan pribadi dan pekerjaan sebagai dosen? Dukungan seperti apa yang mereka butuhkan baik di ranah pribadi (rumah tangga) maupun ranah profesional (kampus)?

Signifikansi penelitian ini antara lain: pengetahuan terhadap tantangan, kendala, dan harapan dosen perempuan berpotensi menjadi masukan untuk menghadirkan dukungan sistem/ struktural yang tepat agar terciptanya dunia kerja dan domestik yang adil dan suportif khususnya bagi dosen perempuan di Indonesia, khususnya selama pandemi Covid-19.

Feminisme adalah sebuah pergerakan untuk menghapuskan seksisme, eksploitasi seksual, serta penindasan (hooks 1984 dalam Tong 2018). Bell hooks (2015) menyebutkan kecenderungan bias kelas dalam pembahasan sebagian feminis terkait dunia pekerjaan. Hal ini tercermin dari anggapan bahwa kemerdekaan hanyak milik perempuan yang keluar rumah untuk bekerja. Padahal menurut hooks, konsepsi bekerja tidak sama bagi setiap orang dari kelas sosial berbeda. Perempuan dari kelas pekerja atau buruh tentu keluar rumah untuk bekerja, namun hal tersebut tidak menjamin mereka bebas dari eksploitasi dan penindasan. Kemerdekaan bekerja dalam konteks ini hanya dimiliki oleh perempuan yang memiliki pekerjaan bergaji tinggi. Hooks kemudian menjelaskan, pergerakan yang baik dapat terjadi apabila para feminis memusatkan perjuangan mereka dalam hal perbaikan kondisi kerja, dan peningkatkan standar upah serta dukungan pencarian pekerjaan bagi perempuan lintas kelas. Lebih lanjut, hal ini juga dapat menghancurkan pelanggengan konsep patriarki yang cenderung memandang sebelah mata pekerjaan bergaji rendah, sukarela, atau tidak berbayar seperti ibu rumah tangga sebagai kegiatan yang tidak berharga. hooks juga mengkritik pergerakan feminis yang hanya memandang nilai pekerjaan dengan kaca mata penghargaan yang diberikan laki-laki. Seakan-akan, sebuah pekerjaan itu hanya bernilai, jika laki-laki mengakuinya. Alhasil, posisi seperti ini hanya menjadi semacam cermin dari bagaimana laki-laki menilai perempuan. Oleh karena itu, penting bagi para feminis untuk menghargai setiap jenis pekerjaan yang perempuan lakukan, dan berjuang mengubah kondisi kerja yang lebih baik secara lintas kelas. Terakhir, Soujourner Truth turut menyatakan pentingnya perempuan untuk tidak sekadar berbicara, namun bertindak dalam usaha untuk mencapai keadilan (Tong, 2018). Dari penjelasan di atas, menurut kami terdapat beberapa konsep penting. Pertama, dalam menganalisis kondisi kerja perempuan, aspek kelas sosial adalah komponen tidak terpisahkan. Kedua, baik kerja berbayar maupun tidak berbayar sama-sama berharga bagi perempuan: yang paling penting adalah bagaimana kondisi kerja mereka, apakah adil ataukah penuh penindasan. Terakhir, pembebasan perempuan memerlukan usaha yang aktif, tidak cukup dengan berbicara, apalagi menunggu keadilan datang sendiri layaknya hadiah.

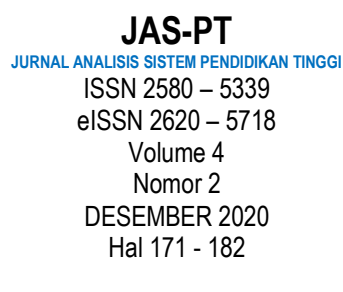

FORUM DOSEN INDONESIA 


\section{METODE PENELITIAN}

Penelitian kualitatif ini melibatkan lima belas dosen perempuan yang berasal dari berbagai perguruan tinggi negeri dan swasta di Sumatra dan Jawa. Mereka berusia 27 sampai 45 tahun. Sebagian dari mereka adalah pegawai tetap (gaji Rp. 2 sampai 5,7 juta per bulan), sementara sebagian lain berstatus pegawai tidak tetap (gaji 1,5 sampai 3 juta per semester). Sebagian dari mereka memutuskan bekerja tambahan untuk memenuhi kebutuhan hidup, seperti di bidang tani, bisnis, bimbingan belajar, atau pada instansi lain (tidak disebutkan). Bagi mereka yang berstatus dosen tetap, sebagian dari mereka mendapatkan tambahan penghasilan dari tunjangan sertifikasi dosen.

Terkait status perkawinan, $80 \%$ dari responden sudah menikah. Beberapa dari mereka tidak memiliki anak, dan sebagian lain memiliki anak sebanyak satu sampai tiga orang. Para responden kebanyakan tinggal dengan keluarga inti, sementara sebagian lain tinggal dengan keluarga besar, atau tinggal sendirian. Dalam hal kepemilikan rumah, mereka juga terbagi. Sebagian memiliki rumah pribadi, sebagian menyewa rumah, dan sebagian lain menumpang di rumah milik orang tua atau keluarga. Berhubung sebagian temuan menyinggung kelemahan institusi, kami menyamarkan identitas dan afiliasi para responden agar informasi yang mereka sampaikan tidak membahayakan karir mereka.

Metode pengambilan data seluruhnya berlangsung mulai dari bulan Agustus hingga Oktober 2020, melalui wawancara mendalam secara daring. Sementara pendalaman informasi terhadap sebagian temuan kami lakukan via panggilan telepon atau aplikasi Whatsapp. Prosedur wawancara daring ini memiliki beberapa kelebihan, khususnya dalam aspek kesehatan selama pandemi Covid-19. Selain itu, untuk topik-topik yang sensitif atau kontroversial, metode daring dapat memudahkan responden yang ingin berpartisipasi secara anonim (Holge-Hazelton 2002 dalam Brinkmann 2014). Walau kemudian, kekurangan lain juga muncul, seperti sebagaian peserta terkesan enggan menjawab secara rinci pertanyaan-hal ini kami coba lengkapi dengan wawancara lanjutan via telepon atau Whatsapp.

Untuk menganalisis temuan, kami menggunakan pendekatan konsepsi ulang hakikat pekerjaan yang dikemukakan oleh feminis Gloria Jean Watkins (bell hooks). Kekurangan riset ini secara terbatas hanya melibatkan dosen perempuan, padahal di kampus juga ada perempuan-perempuan pekerja lain di posisi tenaga admistratif, tenaga kebersihan, dan tenaga keamanan. Kekurangan tersebut mudah-mudahan dapat kami atau peneliti lain tutupi di penelitian-penelitian berikutnya.

\section{HASIL DAN PEMBAHASAN}

\section{Dosen tetap dan tidak tetap}

Dalam sub temuan ini, kami akan membahas perbedaan dosen tetap dan tidak tetap. Di pembahasan selanjutnya, kami akan mengkaitkan penjelasan ini dengan bagaimana implikasi kondisi tersebut terhadap kehidupan mereka ketika pandemi Covid-19. Merujuk Permendikbud no. 49 tahun 2014 tentang Standar Nasional Pendidikan, rasio dosen tetap dan mahasiswa adalah satu banding dua puluh untuk rumpun ilmu IImu

JAS-PT

JURNAL ANALISIS SISTEM PENDIDIKAN TINGGI ISSN $2580-5339$ eISSN $2620-5718$

Volume 4

Nomor 2

DESEMBER 2020

Hal 171 - 182

FORUM DOSEN INDONESIA
Pengetahuan Alam, dan satu banding tiga puluh untuk studi IImu Pengetahuan Sosial. Artinya, semisal di sebuah Prodi IImu Komunikasi jumlah mahasiswa adalah tiga ratus orang, maka jumlah dosen tetap seharusnya adalah sepuluh orang. Hal ini penting kami jelaskan karena di lapangan, realitas yang terjadi tidak selalu baik-baik saja, dan berimplikasi kepada munculnya profesi dosen tidak tetap.

Setiap tahun, tidak jarang jumlah mahasiswa di sebuah perguruan tinggi terus bertambah dikarenakan ekspansi kampus menambah jumlah gedung guna bersaing di era 
neoliberalisme pendidikan. Pertambahan jumlah mahasiswa, tidak otomatis menambah jumlah dosen tetap. Di kampus negeri khususnya, perekrutan dosen tetap (baik PNS atau non-PNS) mesti dilalui perguruan tinggi dengan mengusulkan jumlah kebutuhan dosen kepada direktoral jenderal kementerian yang berkepentingan. Hasil pengusulan sering tidak sesuai dengan kebutuhan di lapangan. Hal ini disiasati oleh kampus dengan merekrut dosen tidak tetap atau sering pula disebut dosen luar biasa (DLB). DLB adalah kelas sosial terendah di dunia perdosenan. Di sebagian kampus, mereka bahkan tidak memiliki surat perjanjian kerja, dan hanya dibekali dengan surat keputusan (SK) yang isinya sudah tidak bisa dinegosiasikan lagi. DLB biasanya hanya mendapatkan hak berupa honorarium per tatap muka. Di sebuah perguruan tinggi di bawah Kementerian Agama misalnya, honorarium berkisar dari Rp.50.000,- hingga Rp.70.000,- per tatap muka, dan dibayarkan per semester, bukan per bulan. Perhitungan tersebut tentu tidak adil mengingat proses pengajaran tidak hanya berlangsung saat tatap muka, melainkan harus diawali oleh persiapan materi, dan diakhiri oleh proses evaluasi yang memakan waktu tidak sedikit. Ditambah lagi waktu pencaiaran honorarium yang durasinya tidak masuk akal. Selain itu, DLB juga acap kali dikecualikan dari asuransi kesehatan serta pelatihan pengembangan profesional. Walau perguruan tinggi tidak sepenuhnya bersalah dalam ketidakadilan ini, namun mereka sebenarnya memiliki kuasa untuk mendesain kondisi kerja yang lebih baik bagi para dosen tidak tetap, misalnya dengan mengupayakan butir-butir di SK yang lebih adil. Namun, itikad itu pun jarang terlihat, dan diperparah dengan kurangnya transparansi, tidak terbukanya ruang untuk berdiskusi terkait kondisi kerja, serta pandangan bahwa fenomena tersebut adalah wajar dan natural terjadi pada dosen-dosen yang baru berkarir. Di samping itu, DLB dihadapkan dengan lemahnya perlindungan kerja di kampus, dan ketiadaan serikat dosen. Perguruan tinggi dapat dengan mudah memberhentikan DLB yang vokal, dan menggantinya dengan tenaga baru yang terus hadir setiap tahunnya.

Penjelasan tersebut secara umum memberikan gambaran tentang perbedaan kondisi kerja antara dosen tetap dan dosen tidak tetap yang sudah langgeng dari sebelum pandemi Covid-19.

\section{Dosen Perempuan Dan Perguruan Tinggi}

Selama pandemi Covid-19, seluruh responden dalam penelitian ini mengaku bekerja dari rumah. Namun, beberapa dari mereka terpaksa ke kampus setiap hari kerja untuk mengisi daftar kehadiran secara manual. Kebijakan seperti ini mencerminkan respon buruk perguruan tinggi terhadap pandemi. Pertanyaannya adalah, jika pembelajaran bisa dilangsungkan daring, mengapa untuk kegiatan yang sepele seperti tanda tangan kehadiran mesti manual?

Isu penggunaan teknologi juga muncul, khususnya pada dosen perempuan yang sudah berusia lanjut. Mereka memerlukan waktu lebih banyak untuk beradaptasi dengan teknologi ajar dibandingkan dengan dosen berusia muda. Fenomena ini semestinya tidak melulu kita lihat sebagai kekurangan individu, tapi juga institusi yang abai dalam mengikuti tren pendidikan daring, sehingga tidak memikirkan mengadakan pelatihan bagi para dosen jauh-jauh hari sebelum pandemi. Pelatihan penggunaan teknologi daring sendiri yang mulai marak akhir-akhir ini kami duga sebagai tindakan reaktif menghadapi pandemi, alih-alih respon visioner dalam membaca perkembangan teknologi ajar. Dalam temuan penelitian, sebagian dosen mengaku mendapatkan pelatihan daring. Namun sebagian lain hanya mendapatkan satu kali pelatihan, dan ada pula yang tidak memperoleh pelatihan sama sekali.

$\mathrm{Hal}$ ini pun belum termasuk pembahasan tentang kesenjangan sosial antara sesama dosen, serta mahasiswa dalam mengakses teknologi pendidikan. Dosen tidak tetap

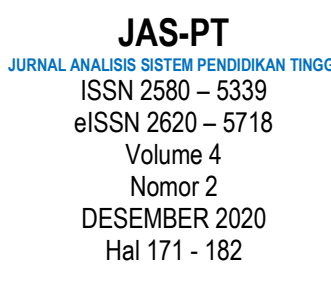

FORUM DOSEN INDONESIA 
khususnya memiliki problem dalam pemenuhan kebutuhan dasar hidup, apalagi untuk pengadaan akses internet yang diperlukan dalam waktu sedikitnya 75 menit per mata kuliah. Sebagian dari mereka sempat dijanjikan kuota internet untuk oleh kementerian melalui kampus, namun ada dari mereka yang tidak mendapatkan sama sekali, dan mesti mengeluarkan uang pribadi.

Selanjutnya, sebagian dosen khususnya mereka yang dalam posisi tidak tetap, tidak menerima bantuan apapun dari kampus, padahal pemerintah daerah mereka sempat memberlakukan pembatasan sosial berskala besar (PSBB). Mereka mengharapkan, paling tidak kampus memberikan dukungan berupa bantuan sembako, berhubung ketika PSBB tidak hanya kampus yang tutup, tapi juga lini-lini kerja sampingan seperti bimbingan belajar yang menjadi tumpuan penghasilan tambahan.

\section{Dosen Perempuan Dan Rumah Tangga}

Isu selanjutnya adalah peran ganda dosen perempuan di rumah. Seorang dosen mengaku, dia kerap diharapkan untuk mengerjakan pekerjaan rumah di jam-jam kerja. Keluarga besarnya beranggapan, keberadaannya di rumah adalah cermin dari banyaknya waktu luang. Penelitian ini menemukan hal ini khas terjadi pada pasangan suami-istri yang belum mampu membeli atau menyewa rumah, dan terpaksa menumpang di rumah orang tua atau keluarga lainnya. Di samping itu, mereka semacam memiliki utang budi untuk membantu kegiatan di rumah itu (seperti memasak dan membersihkan rumah) karena telah diizinkan menumpang secara gratis.

Di rumah tangga dosen yang tinggal di rumah pribadi, isu yang muncul adalah terkait perawatan anak. Mereka kesulitan merawat anak, apalagi bagi dosen yang memiliki anak lebih dari satu, dan ditambah lagi jika anak-anak sudah bersekolah. Beban perawatan ditambah dengan pendidikan. Hal ini terasa memberatkan apabila suami tidak suportif dalam membantu.

\section{Dosen Perempuan Dan Harapan}

Dari universitas, dosen perempuan berharap adanya bantuan finansial dan sembako untuk menunjang kehidupan selama pandemi. Mereka juga berharap ada bantuan kuota internet untuk memastikan pembelajaran daring berjalan dengan lancar. Intinya, salah seorang dosen menyampaikan, dukungan tersebut mereka perlukan untuk membantu terwujudnya Tri Dharma Pendidikan. Namun ada pula dosen perempuan yang tidak mengharapkan apa-apa dari kampus, khususnya mereka dalam posisi tidak tetap. Bagi mereka honorarium sudah memadai apalagi jika dibayarkan tepat waktu.

Lebih lanjut, seorang dosen menyampaikan, ini saatnya bagi kampus mempersiapkan diri lebih matang dalam hal pembelajaran jarak jauh. Misalnya, kampus dia harapkan berinvestasi dalam membangun serambi (platform) daring sendiri, seperti situs, yang dapat para dosen gunakan secara gratis sebagai media pembelajaran. Hal tersebut juga membutuhkan pelatihan teknologi pendidikan yang layak dan berkualitas. Bukan hanya satu-dua kali pertemuan saja. Selain itu, dosen juga memerlukan dukungan alat yang mumpuni, seperti laptop dan hp yang layak untuk mengadakan perkuliahan daring. Bagi beberapa dosen, mereka mesti mengajar dari Senin hingga Sabtu, ditambah lagi dengan

JAS-PT

JURNAL ANAUSIS SISTEM PENDIDIKAN TINGG ISSN $2580-5339$ eISSN $2620-5718$ Volume 4 Nomor 2 DESEMBER 2020 Hal 171 - 182

FORUM DOSEN INDONESIA adanya rapat daring yang tak jarang berlangsung hingga malam hari. Hal tersebut membuat laptop atau hp mereka mengalami penurunan kapasitas yang lebih cepat. Kampus perlu tahu bahwa tidak semua dosen mampu mengganti peralatan tersebut seketika. Dukungan institusi vital perannya untuk mendukung para dosen bekerja dengan lebih baik dan lancar.

Kemudian, responden juga menyampaikan, perlunya kampus memberikan dukungan nonmaterial kepada dosen. Saat pandemi, beban kerja dosen perempuan pasti 
bertambah karena itu mereka membutuhkan dukungan mental seperti pengadaan konseling psikolog, atau kegiatan silaturahmi virtual yang memudahkan mereka bertemu sejawat untuk saling berbagi selama pandemi ini. Kampus juga mereka harapkan beradaptasi dengan kebijakan yang lebih masuk akal, seperti penghapusan kebijakan mengisi kehadiran manual dan menggantinya ke mode daring. Sebagian dosen menyebutkan bahwa kampus bisa mengikuti contoh-contoh kebijakan yang telah dijalankan oleh perusahaan-perusahaan profesional (tanpa menyebutkan contoh perusahaan) yang adaptif dan suportif terhadap kebutuhan karyawan. Hal ini menjadi penting karena mereka melihat sebagian kampus masih beraktivitas seakan-akan sekarang pandemi tidak ada, dan semua normal-normal saja. Hal ini salah satunya terlihat ketika salah satu kampus terus menambah beban kerja dosen, baik secara daring maupun luring. Bahkan salah seorang dosen menyampaikan, seakan-akan dia sudah tidak memiliki waktu untuk diri dan keluarganya sendiri karena harus menghadiri pertemuan daring yang baru selesai hingga larut malam.

Di ranah keluarga, para responden berharap adanya dukungan dan pengertian yang cukup dari pasangan atau keluarga besar. Keberadaan mereka di rumah semestinya tidak selalu dipandang dan disamakan sebagai keleluasaan waktu. Bahwa sekarang adalah masa yang berbeda di mana rumah juga menjadi kantor di jam-jam tertentu. Hal ini tentu menjadi isu yang lebih sulit bagi pasangan yang masih menumpang di rumah keluarga besar. Terlebih apabila mereka dalam posisi keluarga yang tidak terlampau berada di mana rumah adalah ruang yang terbatas, kecil, dan mereka kesulitan menemukan ruang privat yang dapat digunakan untuk bekerja dan berpisah sejenak dari anggota keluarga lain.

Selain itu, ada pula dosen perempuan yang mengeluhkan ketidaknyaman mereka dalam menitipkan anak dan oleh karenanya terpaksa melakukan tugas perawatan sendiri. $\mathrm{Hal}$ ini terutama terjadi manakala tidak semua tempat memperlakukan protokol kesehatan yang tepat, sehingga ada kekhawatiran dengan menitipkan anak, mereka justru rentan terlular Covid-19. Walau ketika perawatan anak difokuskan di rumah, hal ini dapat mengurangi konsentrasi dosen perempuan dalam bekerja. Ini yang kemudian menjadi poin pentingnya kesepahaman pasangan terkait pekerjaan istrinya. Mereka mesti bersedia bernegosiasi agar urusan domestik rumah tangga dan profesional universitas berjalan dengan lancar. Selain itu, seorang dosen menyampaikan, manakala hal tersebut tidak dirawat dengan baik, dia merasakan emosinya sering naik-turun selama pandemi ini. Misalnya, ketika melihat rumah berantakan karena anak-anak seharian di rumah, dan mengingat ekspektasi dari kampus padanya untuk berkinerja maksimal di kelas-kelas daring yang dia asuh. Di sini juga penting kita cermati bahwa tidak semua keluarga dosen dalam penelitian ini mampu menyewa layanan asisten rumah tangga, sehingga mereka harus melakukan segala kewajiban secara mandiri. Beberapa keluarga beruntung karena walaupun mereka tidak memiliki asisten rumah tangga, namun mereka memiliki kerja sama yang baik dengan para anggota keluarga besar. Sehingga tanggung jawab seperti perawatan anak, bisa didelegasikan ketika orang tua bekerja. Jika aspek dukungan ini tidak dirawat dengan baik, seorang dosen menyebutkan, hal ini berimbas pula dengan munculnya mood swing. Dia jadi sulit mengontrol emosi, dan sulit kembali kepada posisi mental yang ideal untuk bekerja dengan baik.

\section{Budaya Patriarki Di Perguruan Tinggi}

Dari sudut pandang institusi, temuan bahwa sebagian kampus tetap menuntut dosen berkinerja maksimal selama pandemi, menunjukkan mereka kurang memiliki empati dan sensivitas gender. Untuk dosen perempuan khususnya, peran ganda sebagai ibu rumah tangga, dan kesulitan menegosiasikan peran di ranah domestik dengan pasangan dan

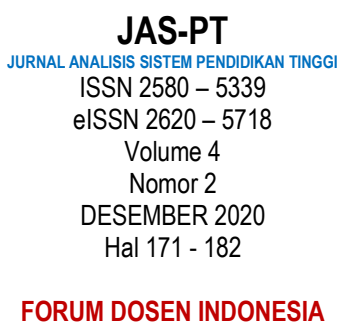

FORUM DOSEN INDONESIA 
anggota keluarga lain, masih terlihat di kehidupan beberapa responden. Namun kebijakan kampus abai mempertimbangkan hal tersebut. Kebijakan kampus yang tidak sensitif ini, kami asumsikan terjadi karena rendahnya representasi akademisi perempuan yang duduk di posisi strategis dalam kepemimpinan perguruan tinggi. Di samping memang pejabat laki-laki tidak memiliki wawasan kesetaraan gender yang memadai. Fenomena ini sekali lagi menunjukkan bahwa budaya patriarki yang memang sudah langgeng di perguruan tinggi dari sebelum pandemi, seperti kurangnya representasi, kesempatan promosi, kesejahteraan emosional dan akademik (Dlamini \& Adams, 2014), memperlihatkan lagi dampak negatifnya bagi pekerja perempuan.

Selain itu, sekalipun tidak secara langsung menjadi bagian dari pembahasan kami di isu dosen perempuan ini, kami memerhatikan beberapa akademisi laki-laki mengalami peningkatan secara signifikan jumlah publikasi akademik mereka selama pandemi Covid-19, dibanding kolega kami yang perempuan. Kami menduga hal ini berhubungan dengan budaya patriarki di rumah tangga, walau tentu memerlukan kajian lanjutan lagi. Di konteks internasional sendiri, fenomena ini benar-benar ada seperti yang telah kami singgung di pendahuluan.

Satu poin penting yang mesti mendapatkan perhatian adalah ada dosen tidak tetap yang tidak mengharap apa-apa selain honorarium — karena memang hanya butir honorarium yang tertulis di SK Pengangkatannya. Di sini, kami menemukan problem lain di samping isu gender, yaitu normalisasi eksploitasi. Sebagian dosen perempuan menganggap apa yang mereka jalani bukanlah masalah, tuntutan untuk berkinerja maksimal selama pandemi dari kampus adalah hal yang wajar. Hal ini menurut kami terjadi karena normalisasi kerja DLB yang telah berlangsung bertahun-tahun. Bahkan ada satu pernyataan dari responden, apabila tidak senang dengan kondisi pekerjaan seperti itu, seorang dosen bisa memilih tidak bekerja di institusi itu. Di situ seakan tanggung jawab untuk berkinerja baik hanya milik dosen seorang, tanpa memandang faktor-faktor yang memengaruhi kinerja itu dari sudut pandang universitas. Padahal posisi DLB tergolong pekerja prekariat yang memiliki ciri khas sebagai kerja fleksibel dan tidak aman (Standing, 2014).

\section{Rumah Tangga Dan Kesetaraan Gender}

Di aspek rumah tangga, kami melihat budaya patriarki yang sudah langgeng di rumah tangga Indonesia, membuat dosen perempuan merasa ada panggilan 'kodrati' untuk bekerja di dapur atau merawat anak, sekalipun mereka memiliki tanggung jawab lain di kampus. Hal yang sama juga menurut kami membuat sebagian suami enteng keluar rumah untuk nongkrong, tidak peduli jika istrinya memiliki pekerjaan profesional yang harus dia kerjakan, anak yang mesti mendapatkan pengasuhan, dan risiko tertular virus di luar rumah. Budaya patriarki sekali lagi dapat melanggengkan superioritas gender lakilaki, dan meninggalkan perempuan dalam rasa bersalah dan tertindas untuk hal-hal yang sebenarnya adalah tanggung jawab bersama. Fenomena ini menjadikan beban tambahan dan stres bagi beberapa responden. Ketiadaan kerja sama dalam keluarga membuat mereka merasa menanggung beban domestik sendirian. bell hooks menyebutkan bahwa feminisme pada hakikatnya adalah untuk semua orang (hooks 2000

JAS-PT

JURNAL ANALISIS SISTEM PENDIDIKAN TINGGI

ISSN $2580-5339$

eISSN $2620-5718$

Volume 4

Nomor 2

DESEMBER 2020

Hal $171-182$

FORUM DOSEN INDONESIA antilaki-laki (hooks, 2015). Aspek ini menjadi poin pentingnya pendidikan feminisme untuk menyasar laki-laki. Feminisme hadir agar kesepahaman dan keadilan wujud di kehidupan setiap orang terlepas dari gender yang mereka miliki. Kami pribadi beranggapan, rumah tangga yang dilandasi ideologi feminisme yang baik akan membuat istri dan suami sama-sama maju sesuai dengan kompetensi yang mereka miliki. 
Selain itu, temuan juga menunjukkan, keluarga yang berada di level ekonomi lemah, berpotensi merasakan dampak yang lebih hebat dari keluarga dengan level ekonomi lebih baik. Ini menjadi aspek yang tidak boleh diabaikan oleh pengambil kebijakan di perguruan tinggi. Misalnya, mereka tidak boleh menyamaratakan kewajiban antara dosen tetap dan tidak tetap, sementara hak mereka dihargai dengan berbeda.

\section{Gender dan agama}

Dalam penelitian ini, mayoritas responden adalah Muslim. Dominasi budaya patriarki sendiri, tentu dapat pula berkaitan dengan bagaimana suatu masyarakat menganut agama. Di negara dengan mayoritas Islam, perdebatan mengenai kesetaraan gender pun bermunculan. Sebuah studi menemukan bahwa penerimaan terhadap konsep patriarki jelas terdeteksi di komunitas Muslim (Alexander \& Welzel, 2011). Namun studi itu melanjutkan, penting sebagai catatan bahwa masyarakat Muslim pun tidak homogen bahkan di satu negara sekali pun.

Di Mesir misalnya. Negara itu sangat kokoh memegang penafsiran teks Islam dari Sheikh BinBaz yang konservatif memandang gender. Namun di sana juga muncul figur Nawal El-Saadawi yang dikenal publik sebagai feminis radikal. Dan ada pula Heba Raouf, seorang feminis yang lebih moderat. Raouf sendiri menegaskan bahwa Islam memberi perempuan dan laki-laki hak dan tanggung jawab yang sama (Sidani, 2005). Perempuan menurutnya memiliki peran untuk dimainkan baik di ranah privat maupun publik. Setiap wanita harus diberikan pilihan merdeka untuk menentukan peran yang berbeda di berbagai tahap kehidupannya. Perempuan mesti memperoleh kesempatan untuk berkontribusi dalam segala bidang kehidupan baik di rumah bersama keluarganya, maupun di arena politik dan ekonomi. Karena itu, Raouf menegaskan bahwa ketika seorang perempuan memiliki kompetensi, maka dia harus diberikan kesempatan yang setara layaknya laki-laki yang berkompetensi. Lebih lanjut, dia menekankan bahwa perempuan berhak menduduki posisi kepala negara atau hakim.

Walaupun Raouf juga dikritik oleh cendekiawan lain terkait kecenderungannya memosisikan rumah tangga sebagai wilayah feminin (McLarney, 2010), namun menurut kami poin penting dari pendapat Raouf adalah posisinya dalam menghargai pilihan perempuan sebagai sebuah tindakan yang mesti dihormati terlepas dari domain privat atau publik. Penghormatan terhadap pilihan perempuan menjadikan diri mereka merdeka, alih-alih memandang secara arogan pilihan perempuan, khususnya di ranah privat atau tidak berbayar, sebagai pilihan yang penuh penindasan. Hal ini menurut kami juga senada dengan pendapat bell hooks, yang bertumpu bukan pada di mana perempuan berkarir, tapi bagaimana kondisi kerja di wilayah tersebut.

Di konteks Indonesia sendiri, kurangnya representasi perempuan di bidang agama menjadi tantangan tersendiri dalam mewujudkan kesetaraan gender. Di Aceh misalnya, sebuah studi menyebutkan, ada beberapa tantangan perempuan untuk masuk ke level ulama, di antaranya kultural dan struktural (Zainuddin, 2017). Di masyarakat Aceh, ketika kata ulama disebutkan, maka yang terbayang langsung figur laki-laki. Hal ini membuat secara alam bawah sadar, muncul keraguan di dalam benak perempuan sendiri untuk menyebut dirinya ulama. Selain itu, studi tersebut tidak menampik adanya sifat ambivalen dari ulama laki-laki dalam keterlibatan perempuan di dunia ilmu pengetahuan, termasuk bidang agama.

Pertalian yang erat antara gender dan tafsiran agama ini, dalam hemat kami, turut berpotensi melanggengkan budaya patriarki, misalnya dengan kehadiran fatwa atau tafsiran-tafsiran agama tanpa sensitivitas gender.

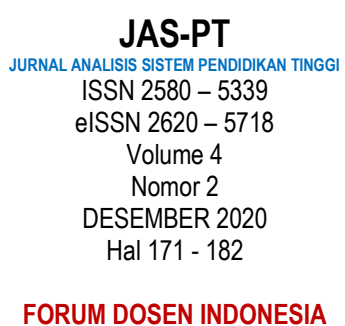

LISIS SISTEM PENDIDIKAN TINGGI

ISSN $2580-5339$

SN $2620-5718$

Nomor 2

DESEMBER 2020

FORUM DOSEN INDONESIA 


\section{PENUTUP}

Temuan di penelitian ini menunjukkan beberapa kesamaan terkait fenomena rumah tangga yang terjadi di Indonesia dan di dunia internasional, misalnya Amerika (Alon et al., 2020), seperti mulai timbulnya kesadaran gender figur suami untuk sama-sama berkolaborasi mengerjakan pekerjaan rumah tangga. Walau pekerjaan rumah selanjutnya, di Indonesia tidak semua rumah tangga terjadi kerja sama seperti itu. Di ranah akademik, kampus-kampus di Indonesia, sesuai instruksi dari Kementerian Pendidikan dan Kebudayaan, serta Kementerian Agama, sudah memberlakukan pembelajaran daring penuh untuk seluruh universitas yang berada di bawah mereka. Hal ini turut menyamakan Indonesia dengan negara lain seperti Australia, Hong Kong, Britania Raya, dan beberapa negara lain (Crawford et al., 2020). Walau tentu, yang membedakannya adalah realitas pekerja di dalam perguruan tinggi sendiri, seperti dosen perempuan di riset ini, yang terkadang luput dari amatan data dan statistik.

Feminisme pada akhirnya memberikan kesempatan pada setiap orang, apapun gendernya, untuk memaksimalkan kompetensi diri, dan meraih kemerdekaan dalam kehidupannya. Titik fokus pada isu perempuan sendiri merupakan upaya penegasan bahwa saat ini, di konteks patriarki yang masih kental di Indonesia, perempuan masih masuk dalam kategori berisiko tinggi menghadapi ancaman eksploitasi di dunia kerja.

Pandemi Covid-19 semakin menegaskan jurang antara harapan ideal dan realitas lapangan bagi perempuan pekerja. Mereka masih saja menghadapi ketidakadilan gender di tempat kerja, budaya patriarki di rumah, dan kini mesti berhadapan dengan ancaman penularan penyakit khususnya bagi mereka yang mencari nafkah di luar rumah.

Harapan tentu masih ada, misal dengan temuan bahwa tidak semua rumah tangga berjalan dengan eksploitatif. Hal ini memberikan ruang dan harapan bahwa feminisme secara pergerakan akan selalu berpotensi untuk dimanifestasikan dalam kehidupan setiap orang. Kami juga melihat pentingnya peran setiap gender, termasuk laki-laki, untuk berkolaborasi dalam mewujudkan dunia yang ramah gender di ruang privat serta publik. Partisipasi lintas gender akan menjadikan gerakan feminisme terkait pada setiap orang, dan mementahkan streotipe bahwa feminisme adalah antilaki-laki.

Dosen perempuan adalah salah satu segmen karir perempuan yang masih rentan terhadap eksploitasi gender. Temuan bahwa bahkan perempuan dengan pendidikan tinggi (minimal Strata-2) masih mengalami eksploitasi, tentu menjadikan perempuan yang berpendidikan lebih rendah berada di jurang risiko yang lebih besar. Hal ini kemudian menjadi pengingat, seperti yang dikemukakan bell hooks, pergerakan feminisme mesti menyentuh seluruh kelas sosial. Hal ini kemudian menjadi pekerjaan serius bagi akademisi yang peduli pada isu gender di pendidikan tinggi agar tidak mengenyampingkan perempuan-perempuan pekerja lain dari aktivitas riset mereka.

\section{DAFTAR PUSTAKA}

Alexander, A. C., \& Welzel, C. (2011). Islam and patriarchy: how robust is Muslim support for patriarchal values? International Review of Sociology, 21(2), 249-276.

JAS-PT

JURNAL ANALISIS SISTEM PENDIDIKAN TING

ISSN $2580-5339$

eISSN $2620-5718$

Volume 4

Nomor 2

DESEMBER 2020

Hal 171 - 182

Alon, T. M., Doepke, M., Olmstead-Rumsey, J., \& Tertilt, M. (2020). The impact of COVID-19 on gender equality. National Bureau of Economic Research.

Andersen, J. P., Nielsen, M. W., Simone, N. L., Lewiss, R. E., \& Jagsi, R. (2020). MetaResearch: Is Covid-19 Amplifying the Authorship Gender Gap in the Medical Literature? ArXiv Preprint ArXiv:2005.06303. 
Brinkmann, S. (2014). Unstructured and semi-structured. The Oxford Handbook of Qualitative Research, 277-299.

Collins, C., Landivar, L. C., Ruppanner, L., \& Scarborough, W. J. (2020). COVID-19 and the gender gap in work hours. Gender, Work \& Organization.

Crawford, J., Butler-Henderson, K., Rudolph, J., Malkawi, B., Glowatz, M., Burton, R., ... Lam, S. (2020). COVID-19: 20 countries' higher education intra-period digital pedagogy responses. Journal of Applied Learning \& Teaching, 3(1), 1-20.

Darmawan, A. A. Y. P., Silviandari, I. A., \& Susilawati, I. R. (2016). Hubungan burnout dengan work-life balance pada dosen wanita. MEDIAPSI, 1(1), 28-39.

Dlamini, E. T., \& Adams, J. D. (2014). Patriarchy: A case of women in institutions of higher education. Perspectives in Education, 32(4), 121-133.

Hermawan, Y., Hermadi, I., \& Sukoco, H. (2020). Sistem Kelayakan Borang Akreditasi Program Studi Menggunakan Fuzzy Inference System. JAS-PT (Jurnal Analisis Sistem Pendidikan Tinggi Indonesia), 4(1), 67 - 76. doi:10.36339/jaspt.v4i1.303

hooks, bell. (2015). Feminist Theory: From Margin to Center. Routledge, Taylor \& Francis Group.

Howe-Walsh, L., \& Turnbull, S. (2016). Barriers to women leaders in academia: tales from science and technology. Studies in Higher Education, 41(3), 415-428.

Karniawati, N. (2013). Kinerja Dosen Perempuan: Studi Relasi Gender di Unikom. JIPSIJurnal IImu Politik Dan Komunikasi UNIKOM, 1.

Kumolohadi, R. (2001). Tingkat stres dosen perempuan UII ditinjau dari dukungan suami. Psikologika: Jurnal Pemikiran Dan Penelitian Psikologi, 6(12), $29-42$.

Manurung, T. M. S. (2017). Pengaruh motivasi dan perilaku belajar terhadap prestasi akademik mahasiswa. JAS-PT (Jurnal Analisis Sistem Pendidikan Tinggi Indonesia), 1(1), 17-26.

McLaren, H. J., Wong, K. R., Nguyen, K. N., \& Mahamadachchi, K. N. D. (2020). Covid19 and Women's Triple Burden: Vignettes from Sri Lanka, Malaysia, Vietnam and Australia. Social Sciences, 9(5), 87.

McLarney, E. (2010). The private is political: Women and family in intellectual Islam. Feminist Theory, 11(2), 129-148.

Mulyana, M., Rainanto, B.H., Astrini, D. and Puspitasari, R., 2020. Persepsi Mahasiswa Atas Penggunaan Aplikasi Perkuliahan Daring Saat Wabah Covid-19. JAS-PT (Jurnal Analisis Sistem Pendidikan Tinggi Indonesia), 4(1), pp.47-56.

Salsabila, H. A., \& Iriyadi, I. (2020). Evaluasi Atas Penerapan Sistem Informasi Akademik Dan Keuangan Terhadap Tingkat Kepuasan Mahasiswa. JAS-PT (Jurnal Analisis Sistem Pendidikan Tinggi Indonesia), 4(2), 137-148.

Sidani, Y. (2005). Women, work, and Islam in Arab societies. Women in Management Review.

Standing, G. (2014). The Precariat. Contexts, 13(4), 10-12. https://doi.org/10.1177/1536504214558209

Tong, R. (2018). Feminist Thought: A More Comprehensive Introduction. Routledge.

Zainuddin, M. (2017). PERAN ULAMA PEREMPUAN DI ACEH (Studi Terhadap Kiprah Perempuan Sebagai Ulama di Kabupaten Bireuen dan Aceh Besar). TAKAMMUL: Jurnal Studi Gender Dan Islam Serta Perlindungan Anak, 6(2), 165-177.

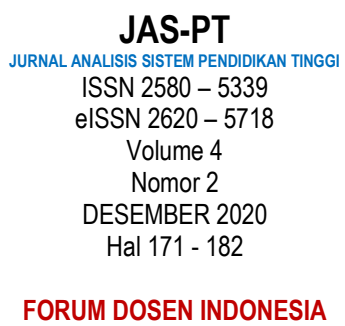

FORUM DOSEN INDONESIA 
Muhammad Haekal bekerja sebagai dosen Bahasa Inggris di Fakultas Ekonomi Islam dan Bisnis, Universitas Negeri Ar-Raniry, sejak 2018. la merupakan alumni Monash University, Australia (Master of Education in Educational Leadership and Policy, 20162018). Dia memiliki minat penelitian dalam isu pendidikan tinggi, keadilan sosial, dan masalah kekerasan sekolah. la dapat dihubungi melalui email muhammad.haekal@arraniry.ac.id.

Ainal Fitri bekerja sebagai dosen IImu Komunikasi di Fakultas Agama Islam Universitas Serambi Mekkah, sejak 2015. la merupakan alumni Universitas Diponegoro, Indonesia (Magister IImu Komunikasi, 2013-2015). Dia memiliki minat penelitian dalam isu komunikasi, studi media, gender, dan minoritas. la dapat dihubungi melalui email ainal.fitri@serambimekkah.ac.id. 